Technical Paper

Doi: http://dx.doi.org/10.1590/1809-4430-Eng.Agric.v42n1e20200128/2022

\title{
CHARACTERIZATION OF GEOSPATIAL, MORPHOMETRIC, AND ENVIRONMENTAL DYNAMICS OF THE MARIANA MICROBASIN IN ALTA FLORESTA-MT, BRAZIL
}

\author{
Marcus H. Martins e Silva ${ }^{*}$, Fernando L. Silva ${ }^{1}$ \\ ${ }^{1 *}$ Corresponding author. Instituto Federal de Mato Grosso - Campus Alta Floresta/ Alta Floresta - MT, Brasil. \\ E-mail: marcus.martins@ifmt.edu.br | ORCID ID: https://orcid.org/0000-0002-9446-1064
}

\section{KEYWORDS \\ environmental monitoring, geotechnologies, water resources.}

\begin{abstract}
River basin environmental diagnosis and monitoring are fundamental for water resource use and conservation plans, as these systems integrate different landscape elements and may undergo impacts and changes of different levels and scales. In this context, this work aimed to characterize the geospatial, morphometric, and environmental dynamics in the Mariana microbasin, in the municipality of Alta Floresta, to provide technical-scientific subsidies for environmental management and planning at a local and regional level. The microbasin was analyzed for morphometric, topographic, and land-use and cover parameters using geospatial data processed in a geographic information system. The microbasin is classified as fourth-order, has a network of 72 channels, and its relief is mostly flat and smooth wavy. Moreover, the soil is predominantly covered by agricultural lands, encompassing $70 \%$ of the area. This feature brings the need to adopt conservation practices for soil management. This study showed the need for continuous environmental monitoring programs and expansion of conservation actions in the studied area.
\end{abstract}

\section{INTRODUCTION}

The disorderly occupation of river basins, especially in the Amazon, increases environmental fragility, impacting these areas environmentally and socio-economically. Oliveira et al. (2019) verified this scenario at the northern end of Mato Grosso State, accelerating soil degradation. Silva \& Bampi (2019) added that the increase in logging, mineral exploration and agricultural monocultures are factors that have significantly contributed to the socioenvironmental transformation of landscapes in this region.

The Mariana microbasin is located in the northern end of Mato Grosso State, in the municipality of Alta Floresta. It is an important environmental system for the maintenance of ecological processes, urban supply, and agricultural activities. However, as highlighted by Polachini et al. (2018), land use and occupation in this municipality has been intense, with deforestation and agricultural activity growing significantly.

Oliveira et al. (2019) stated that the lack of landuse planning often leads to depletion of natural resources due to land degradation, freshwater scarcity, and biodiversity losses. Thus, the intensification of the disorderly occupation of river basins and its consequences highlight the need for environmental studies to support actions and strategies towards environmental planning and management, and conservation of natural resources, especially aquatic environments.

Environmental structures can be understood by integrated analysis, identifying their elements, hierarchies, functions, flows, interrelationships, and interdependence among biotic, abiotic, and anthropic processes. Such analysis allows diagnosing environmental weaknesses and strengths for proper management of resources and territorial and environmental planning and management. According to Pessi \& Loverde-Oliveira (2019), systematic analysis of an environment is the basis for an integrated study of the relationship among its natural elements, enabling management aimed at the conservation of landscape and biodiversity.

Brito \& Grangeiro (2015) emphasized the importance of geoenvironmental analysis of river basins to understand their natural aspects for environmental and territorial planning. These authors also added that studies on a river basin as a unit of geographic space allows an

\footnotetext{
${ }^{1}$ Instituto Federal de Mato Grosso - Campus Alta Floresta/ Alta Floresta - MT, Brasil.
} 
integrated understanding of anthropic actions and their influence on the functioning of environmental dynamics.

As highlighted by Teodoro et al. (2007), the morphometric characterization of a river basin is one of the most important procedures for hydrological or environmental analysis, with a view to understanding and clarifying various issues related to local and regional environmental dynamics. Morphometric analyses enable identifying hydrological behavior trends, which are useful, especially in areas where such data are incipient (Franco \& Santo, 2015).

Geospatial analysis of natural systems by geoprocessing techniques and remote sensing are important tools for water resources management. The advances in geotechnology in recent years have contributed to mapping and monitoring several areas, mainly in terms of earth surface use and cover (Souza et al, 2019).

The relevance of environmental studies for diagnosis and monitoring of water resources is thus evidenced, at different levels, variables, and scales, mainly considering the consequences of the disorderly expansion of human activities to areas of greater environmental sensitivity. Zaiatz et al. (2018) analyzed land-use and-cover changes in the Teles River Basin and found intense anthropization between 1984 and 2014 towards forest cover areas, which showed the highest percentage reduction. The authors also added that geographic information system (GIS) and remote sensing techniques allow a better understanding of land cover changes, with fast and cheap environmental change dynamics analysis. Such analyses are fundamental for planning and decision-making by public policymakers and natural resource management.

Claudino et al. (2020) highlighted that remote sensing and geoprocessing techniques are of fundamental importance for land cover planning in river basins, as they allow for spatial and temporal analyses that reflect the dynamics in these areas. These authors analyzed the physical characteristics of a microbasin in the northern region of Mato Grosso and found significant changes in land cover, mainly due to agricultural activity, besides a low to medium erosive potential due to slope and land cover identified.

Alves et al. (2018) evaluated the environmental fragility of a river basin in southeastern Goiás through physical-natural and land-use and -cover characteristics, using geotechnological tools. The authors identified different fragility levels and recommended conservation strategies for agricultural activities and recovery practices for degraded areas. Finally, they emphasized that the use of techniques to integrate physical characteristics and land use in a GIS environment prove to be effective in a better understanding of environmental fragility in river basins.

In this context, this study aimed to characterize the geospatial, morphometric, and environmental dynamics in the Mariana microbasin, in the municipality of Alta Floresta, to provide technical-scientific subsidies for environmental management and planning at a local and regional level.

\section{MATERIAL AND METHODS}

\section{Study Area}

The Mariana microbasin is located near the urban center of Alta Floresta, in the northern end of Mato Grosso State, at coordinates UTM 600440.29 E and 8908270.66 S (Figure 1). According to IBGE (2019), the municipality has $8,953,191 \mathrm{~km}^{2}$ and a total population of 51,782 inhabitants. The local economy is mainly based on the trade and services sector, logging, and agricultural activities, especially beef cattle and, in recent years, soybeans and corn.

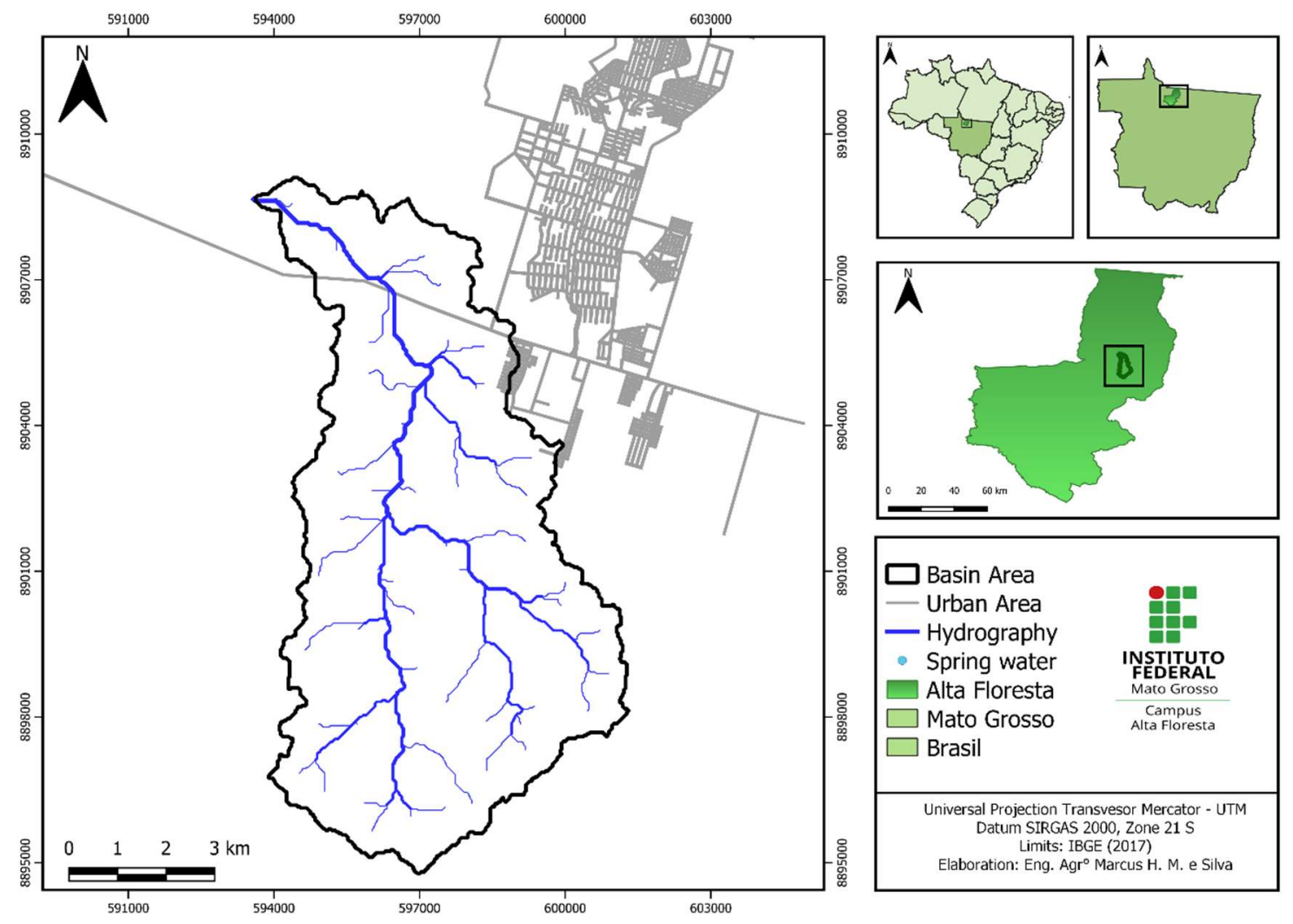

FIGURE 1. Study Area Location Map. 
The local climate is classified as $A w$ and has a bimodal rainfall pattern, with two distinct seasons, a dry winter season and a rainy summer (Alvares et al., 2014). The average annual temperature is $26{ }^{\circ} \mathrm{C}$, and average annual rainfall is high and ranges from 2,800 to $3,100 \mathrm{~mm}$, with rains concentrated between November and May. The municipality is within the Amazon biome, and its floristic composition is formed by Open and Dense Ombrophilous Forest, Seasonal Forest, and Cerrado (Ferreira, 2001). The relief is classified into the following geomorphological units: Southern Amazonia Interplanaltic Depression, Apiacás-Sucunrundi Plateaus, Dissected Plateau of Southern Amazonia, and Residual Plateaus of Northern Mato Grosso (Brasil, 1980).

Besides the regional importance of the rivers Teles Pires, Santa Helena, Paranaíta, Cristalino, and Apiacás, the water resources in the Mariana microbasin are fundamental to the urban water supply of Alta Floresta, as its sources form the Taxidermista river, from where water is collected (Bambolim \& Donde, 2017).

\section{Methodological Procedures and Data Analysis}

The microbasin was delimited using a digital elevation model at a $30 \mathrm{~m}$ resolution (Project Topodata) from the Shuttle Radar Topography Mission - SRTM (http://www.dsr.inpe.br/topodata/). Oliveira et al. (2010) pointed out that automatic basin delimitation by SRTM data processing in a GIS (Geographic Information Systems) environment is advantageous for standardizing layout and minimizing inconsistencies when establishing a water resources management unit.

In the pre-processing, the geographic coordinate system of the DEM (SIRGAS 2000) was projected to UTM Zone $21 \mathrm{~S}$ plane coordinate system, with subsequent removal of spurious depressions and cells using the "Fill Sinks" tool in the pull-down menu of the Analysis Terrain Hydrology. In the processing stage, the tool "Channel Network and drainage basins" was used to obtain the river basin area, flow direction, flow accumulation, drainage density, drainage order, and channel-connectivity sites. Both pre-processing and processing were carried out using the free software QGIS 3.4 integrated with SAGA GIS 3.2.3 algorithms for hydrological analysis.

After microbasin delimitation, the study area was delimited, and hypsometric (altimetry data converted into classes) and slope maps were generated based on the classes proposed by EMBRAPA (1979). Table 1 displays the parameters considered for the morphometric characterization.

TABLE 1. Morphometric parameters for analysis of the Mariana Microbasin.

\begin{tabular}{cc}
\hline Parameter & Method \\
\hline Basin Area & Wisler \& Brater (1964) \\
Basin Perimeter & - \\
Form factor (Kf) & Villela \& Mattos (1975) \\
Circularity Index (Ic) & Schumm (1956) \\
Compactness Coefficient (Kc) & Villela \& Mattos (1975) \\
Drainage density & Villela \& Mattos (1975) \\
Length of main river (L) & Extension from the springs to the mouth \\
Order of the hydrographic network & Strahler (1957) \\
Maximum and Minimum Altitude & Hypsometry \\
\hline
\end{tabular}

For land-use and land-cover analyses, we used SENTINEL 2-A images with 10-meter spatial resolution and 12-bit radiometric resolution (https://scihub.copernicus.eu/dhus/\#/home ) from August 2019, which is the period of least rainfall in the studied region, reducing the percentage of clouds in images.

First, atmospheric correction and area of interest clipping were performed using the pre-processing tools of the Semi-Automatic Classification Plugin (SCP) and Clip Raster plugin, respectively. Then, a true color composite (RGB bands 4, 3, 2) was generated to evaluate classification targets and false color composite (RGB bands 8, 4, 3) due to the high spectral contrast among densely vegetated, pasture, and water body areas, which were subsequently established for classification.

For supervised classification, the SCP plugin - Semiautomatic Classification Plugin (Congedo, 2016) was used, which is available in the QGIS 3.4 software. In the SCP, training samples were added and subsequent image classification was carried out by the Maximum Likelihood method (Maximum Likelihood).

In post-process classification, the accuracy of Confusion Matrix results was verified by Thematic Map
Accuracy Assessment (Llano, 2019), which assesses the accuracy of thematic maps using as reference true-color band images. In this assessment, accuracy is defined as the degree to which a produced map conforms to the reference classification, for which 397 random sampling points were used for verification and agreement. Moreover, from Confusion Matrix results, the Kappa index was calculated (Landis \& Koch, 1977) to assess classification map reliability. For Confusion Matrix calculations, the data were tabulated in an electronic spreadsheet, in which the sum of values forming the main diagonal of the matrix is divided (Hellden et al., 1980), representing the number of correctly classified elements. In the final stage, after the supervised classification, verification of the accuracy of the method used, automatic delimitation of the watershed and extraction of the drainage network, using the Polygonize tool from the Raster menu, the raster files were converted into vectors for area and other calculations morphometric parameters. The raster files were then converted into vectors for area calculation and other morphometric parameters. The values of the supervised classification class areas, slope and total area of the basin were tabulated in electronic spreadsheets 
and from the vector files statistical analysis of absolute and relative frequency was performed.

\section{RESULTS AND DISCUSSION}

The integrated analysis of geospatial, morphometric, physiographic, and land-use aspects in the Mariana microbasin allowed us to spatialize and diagnose its current conditions and simplify its environmental dynamics. Table 2 shows the morphometric parameters of DEM geoprocessing and drainage network characterization of the study area.

TABLE 2. Morphometric parameters of the drainage network of the Mariana microbasin.

\begin{tabular}{|c|c|c|c|c|}
\hline Parameter & & \multicolumn{2}{|c|}{ Unit } & Result \\
\hline Basin Area & & \multicolumn{2}{|c|}{$\mathrm{km}^{2}$} & 64.87 \\
\hline Basin Perimeter & & \multicolumn{2}{|c|}{$\mathrm{km}$} & 46.37 \\
\hline Axial Length & & \multicolumn{2}{|c|}{$\mathrm{km}$} & 14.35 \\
\hline Form factor (Kf) & & \multicolumn{2}{|c|}{ dimensionless } & 0.31 \\
\hline Circularity Index (Ic) & & \multicolumn{2}{|c|}{ dimensionless } & 0.37 \\
\hline Compactness Coefficient (Kc) & & \multicolumn{2}{|c|}{ dimensionless } & 1.61 \\
\hline Drainage density & & \multicolumn{2}{|c|}{$\mathrm{km} / \mathrm{km}^{2}$} & 1.06 \\
\hline Length of main river (L) & & \multicolumn{2}{|c|}{$\mathrm{km}$} & 16.86 \\
\hline Maximum Altitude & & \multicolumn{2}{|c|}{$\mathrm{m}$} & 378 \\
\hline Minimum altitude & & \multicolumn{2}{|c|}{$\mathrm{m}$} & 251 \\
\hline \multicolumn{5}{|c|}{ Hydrographic network order } \\
\hline & $1^{\text {st }}$ Order & $2^{\text {nd }}$ Order & $3^{\text {rd }}$ Order & $4^{\text {th }}$ Order \\
\hline Number of watercourses & 48 & 20 & 3 & 1 \\
\hline Total length (km) & 34.64 & 14.34 & 10.72 & 9.38 \\
\hline Average length (km) & 0.72 & 0.71 & 3.57 & 9.38 \\
\hline
\end{tabular}

The microbasin area is $64.87 \mathrm{~km}^{2}(6,487 \mathrm{ha})$, which represents less than $1 \%$ of the municipal territory, with an axial length of $14.35 \mathrm{~km}$ and a perimeter of $46.37 \mathrm{~km}$. This geosystem can be classified as a large basin. According to Wisler \& Brater (1964), basins with a total area of fewer than $26 \mathrm{~km}^{2}$ are classified as small, while those with a total area above this are classified as large basins. The Mariana microbasin is located adjacent to the urban core, which facilitates agriculture development, especially fruit orchards and vegetable gardens, given its proximity to consumers. According to Cochev et al. (2015), the microbasin analyzed in our study is part of a set of 12 microbasins surrounding the urban core of Alta Floresta.

The form factor (Kf) and compactness coefficient (Kc) were 0.31 and 1.61 , respectively. Therefore, the basin is elongated in shape and less susceptible to flooding under normal meteorological conditions. According to Villela \& Mattos (1975), basins with a form factor below 1.0 have low circularity, thus less prone to flooding. Furthermore, the more irregular the basin, the greater its compactness coefficient; therefore, coefficients above 1.0 will indicate low susceptibility to flooding.

The microbasin also had a circularity index of 0.37 , which corroborates its elongated shape and indicates its lower flooding trend. It is because the value is far from 1.0 and promotes a better flow dynamic. According to Schum (1951), circularity index values lower than 0.51 suggest basins with a more elongated shape, whereas values higher than 0.51 indicate more circular basins, favoring flooding.
The drainage system of basins must be analyzed to obtain critical water outflow velocities (maximum and minimum) and understand their degree of development (Cardoso et al., 2006). The analyzed microbasin had a drainage density of $1.06 \mathrm{~km} / \mathrm{km}^{2}$. According to Villela \& Mattos (1975), such density indicates a regular drainage system, which varied from 0.5 and $3.5 \mathrm{~km} / \mathrm{km}^{2}$. Thus, in the adopted mapping scale, the contribution surface is much higher for the number of channels. Importantly, the greater the drainage density, the greater the capacity of the basin to drain water to the outlet. Cardoso et al. (2006) also emphasized that understanding drainage density helps in planning basin management.

After hydrographic network ordering (Figure 2), we noted that most of the watercourses are of the first order, totaling 48 courses and averaging $0.72 \mathrm{~km}$ in length. However, even when DEM showed lower altitude points with first-order channels, these can behave like intermittent watercourses, once they may or may not have water flow at certain times of the year. First-order channels do not have tributaries and are the smallest identifiable ones characterized by intermittent drainage (Strahler, 1957; Tucci, 2004). The hydrographic network analyzed is composed of 72 channels, with a total length of $69.08 \mathrm{~km}$ and the main river $(16.86 \mathrm{~km})$ in a south-north direction. According to Strahler (1957), this microbasin can be classified as a $4^{\text {th }}$ order and dendritic type drainage network pattern. 


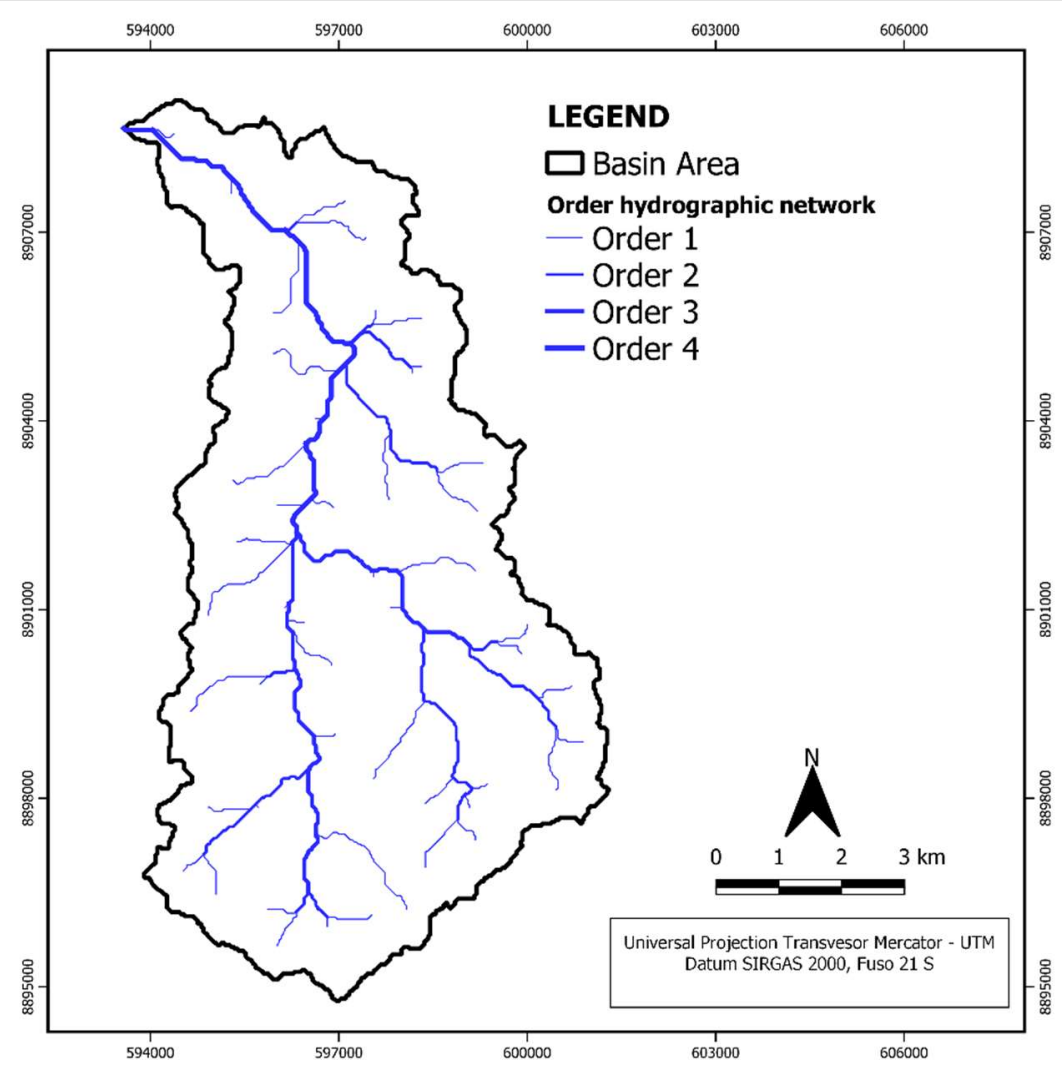

FIGURE 2. Hydrographic network order in the Mariana microbasin, Alta Floresta - MT.

Among other factors, relief, altitude, and slope in the contribution area of a microbasin have a direct influence on surface runoff and potential erosive processes. Therefore, these aspects have to be spatially characterized

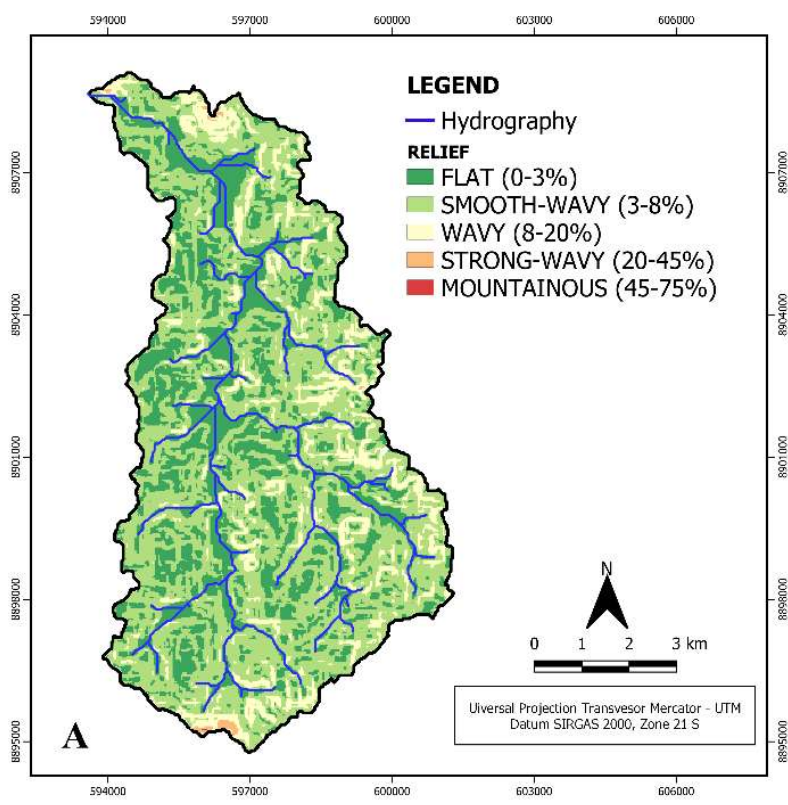

for land-use planning and managing, as well as protected area delimitations.

Figure 3 shows the Slope map and the Hipsometric map of the study area.

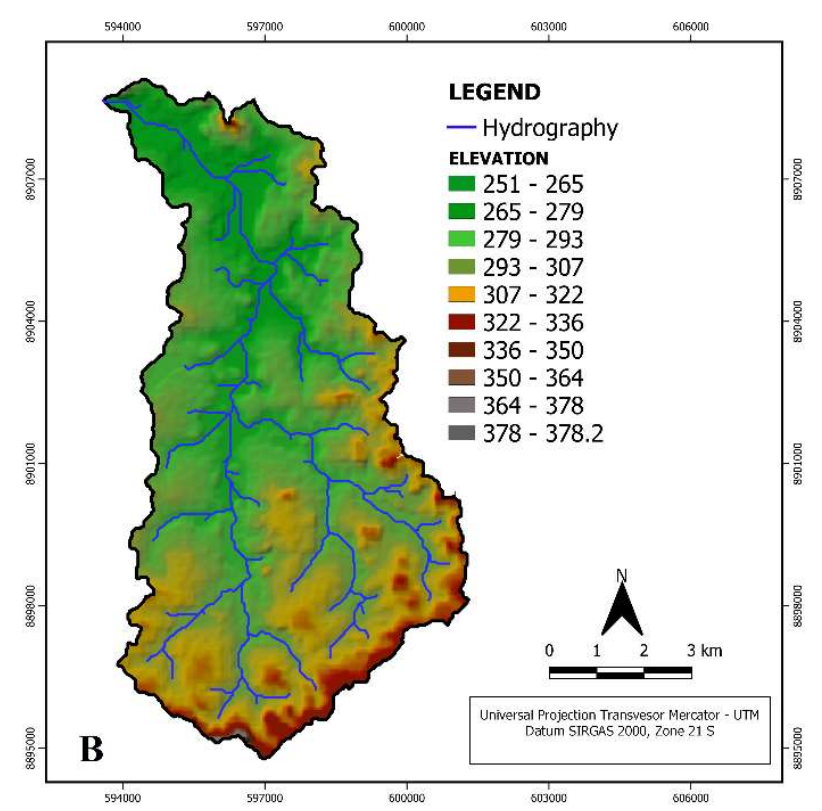

FIGURE 3. Slope Map (A) e Hypsometry Map (B) of the Mariana microbasin, Alta Floresta - MT.

Five relief classes (Table 3) were identified in the microbasin. Predominant classes were flat and smoothwavy, which ranged between $0-3 \%$ and $3-8 \%$, respectively. The altimetric amplitude was $127.2 \mathrm{~m}$, with a flow concentration between 251 and 307 meters. Specifically for slope factors, these two relief classes may indicate land suitability for farming. However, soil and water conservation practices should be implemented, and other factors such as soil fertility, suitability for mechanization, erosion susceptibility, and crop characteristics must be also considered.

The association of a predominant smooth-wavy relief and agricultural activities in the Mariana microbasin highlights the importance of conservation practices to avoid 
erosive processes compromising productive activities. However, more detailed evaluations and erosion predictor models can contribute to a better understanding of runoff dynamics. According to Gonçalves et al. (2007), the relief measure evolves from flatter to more sloping areas, water infiltration into the soil reduces and surface runoff increases concomitantly, tending to form a linear flow concentration.
According to Cardoso et al. (2006), the slope influences the relationship between rainfall and runoff in a basin, especially due to increases in surface runoff speed and reductions in water infiltration into the soil. Therefore, the topography is a key factor in predictive erosion models, as it directly influences the rate and volume of surface runoff of rainwater (Claudino et al., 2018).

TABLE 3. Distribution of slope classes in the Mariana microbasin, Alta Floresta - MT.

\begin{tabular}{|c|c|c|c|}
\hline Slope Class & Relief & Area (ha) & $\%$ \\
\hline $0-3 \%$ & Flat & $2,088.55$ & 32.19 \\
\hline $3-8 \%$ & Smooth-wavy & $3,646.26$ & 56.84 \\
\hline $8-20 \%$ & Wavy & 734.92 & 11.32 \\
\hline $20-45 \%$ & Strong-wavy & 17.05 & 0.26 \\
\hline $45-75 \%$ & Mountainous & 0.37 & 0.005 \\
\hline Total & & $6,487.17$ & 100 \\
\hline
\end{tabular}

Soil physical properties, such as texture, porosity, and density, are directly associated with erosive processes (Simonetti et al. 2018) and hence sediment loading into watercourses. According to a study by the Mato Grosso State Department of Planning (Mato Grosso, 2001), the Mariana microbasin is in a region with a predominance of Argissolos (Ultisols), in addition to Neossolos (Entisols) and Plintossolos (Plinthosols) at smaller proportions. These soils, in turn, have characteristics that require specific management practices, e.g., Argissolos (Ultisols) are naturally susceptible to erosion. Roboredo et al. (2017) evaluated the socio-environmental degradation in the Mariana microbasin and the perception of rural families about the recovery of permanent preservation areas; they concluded that the majority of farmers perceive environmental recovery as essential, but emphasize the need to build contour lines and terraces for soil conservation.

Land cover in areas of alternative use, conservation of permanent preservation areas, and type of agricultural management are also associated with erosion intensity, watercourse siltation and eutrophication, as well as soil fertility losses. Guidolini et al. (2020) stated that inadequate land-use planning leads to erosion, annual losses in crop yield, and poor water quality. Figure 4 shows that the surface of the Mariana microbasin is mostly occupied by agricultural production areas.

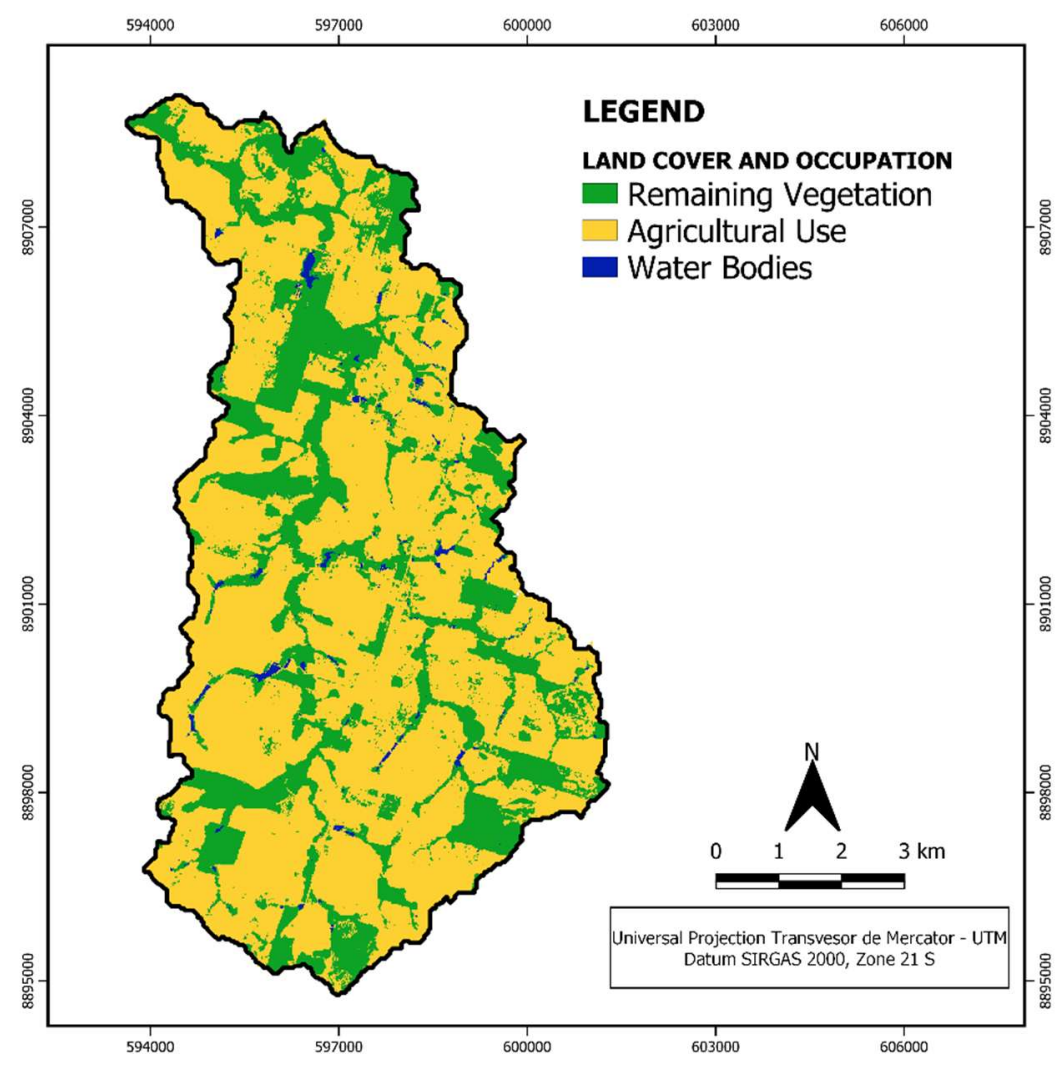

FIGURE 4. Land Cover and Occupation Map of the Mariana microbasin, Alta Floresta - MT. 
Based on the Sentinel 2 image classification (Table 4), we found that $70.63 \%$ of the area in the micro-basin is destined for alternative land use, especially cattle-raising, which is one of the main products of the municipal economy (Silva et al., 2019) and for the northern Mato Grosso as well, with Alta Floresta having one of the largest cattle herds in the state. Such an expressive land occupation emphasizes the importance of rational pasture management to maintain well-adjusted stocking rates, avoiding soil compaction and hence surface runoff, disaggregation, and transport of soil particles, as well as maintaining good forage stands to ensure an optimal soil coverage. For Tucci \& Clarke (1997), bare soil under compaction can have its infiltration capacity dramatically decreased, increasing surface runoff.

TABLE 4. Absolute and relative contribution of land cover and occupation classes in the Mariana microbasin, Alta Floresta MT, 2019.

\begin{tabular}{|c|c|c|}
\hline Class & Area (ha) & $(\%)$ \\
\hline Remaining Vegetation & $1,843.90$ & 28.42 \\
\hline Agricultural use & $4,582.31$ & 70.63 \\
\hline Water bodies & 60.45 & 0.93 \\
\hline Total & $6,487.66$ & 100 \\
\hline \multicolumn{3}{|c|}{ Rating Accuracy Rating Index } \\
\hline Global Accuracy & 0.93 & \\
\hline Global Kappa Index & 0.85 & \\
\hline
\end{tabular}

The accuracy values in Table 4 denotes that the thematic classification can be considered excellent, as the Global Accuracy and Kappa index showed that more than $80 \%$ of the verified points were correctly classified. According to the classification of Landis \& Koch (1977), the Kappa index obtained in our study indicates an excellent agreement, as the higher the coefficient (i.e., closer to 1), the better the classification accuracy.

By analyzing vegetation cover in the Mariana microbasin using the supervised classification of Landsat 5 and 8 imageries between 1990 and 2016, Bambolim \& Donde (2017) found a decrease in forest cover, mainly between 1990 and 2000. According to these authors, about $54 \%$ of the land was covered by native forest in 1990 , decreasing to $25.5 \%$ in 2000; however, in 2010, it increased to $27.5 \%$ but subsequently decreased to $25.8 \%$ in 2016 . As verified in our study, the native forest area in August/2019 (satellite image acquisition period) was $1,843.90$ ha (28.42\%). If compared to the study of Bambolim \& Donde (2017), forest cover increased in 2019. This increase can be associated with the evolution of preservation areas, integrating factors such as the adoption of conservationist practices by farmers and public incentives for the recovery of degraded preservation areas, in addition to more inspection by environmental agencies.

As for Roboredo et al. (2017), environmental recovery in Alta Floresta and consequently Mariana microbasin has advanced due to rural environmental registry system, georeferencing of farms, and supplying of inputs for permanent preservation area restorations (e.g., seedlings, stakes, and wire). These actions have been financed with resources from the Amazon Fund of the National Bank for Economic and Social Development.

As the Mariana microbasin is an area under intense agricultural use, permanent preservation and legal reserve areas are essential to maintain its water dynamics. Tucci \& Clarke (1997) highlighted that vegetation plays a fundamental role in energy balance, water volume, and directional flows in river basins. Therefore, hydrodynamics in these geosystems depends on the structural complexity of vegetation and its interaction with climatic and topographic elements.

About the agricultural activity, annual crop areas have increased in the municipality in recent years, especially soybeans and corn, both in rotation systems and integration with beef cattle. Therefore, soil conservationist practices, such as no-tillage, level planting, and terracing, must be considered. In this context, the land suitability classification by the SEPLAN-MT for these areas is corroborated as 2 (a)bc, that is, with regular suitability for crops at medium and high technology management levels and restricted at low technological management level (Mato Grosso, 2001).

In Alta Floresta, the soybean plantation area grew between the 2016/2017 and 2019/2020 harvests by approximately $28 \%$, which means an increase of 3,000 ha (SOJAMAPS, 2020). Given the importance of this microbasin for urban water supply and expansion of agricultural activities where different chemical inputs are used, further studies are required to monitor land use and occupation, incorporating quality assessment parameters to characterize potential impacts and/or changes in water availability and quality.

\section{CONCLUSIONS}

The environmental dynamics of the Mariana microbasin has been influenced throughout its occupation process by gradual farming development. The predominant land cover class is agricultural production, representing around $70 \%$ of the contribution area; therefore, conservationist soil management practices must be adopted. Forest areas stand for a little more than $28 \%$ of the land cover and are concentrated mainly along drainage network lines, corresponding to permanent preservation areas that require integral conservation to maintain their ecosystem functions.

Environmental analysis by geoprocessing tools, geographic information systems, and digital elevation model allowed to identify the physiographic and morphometric characteristics of the Mariana Microbasin such as catchment area, slope variations, drainage network location, flooding trend indexes, and different land-use and -cover classes. The 
microbasin has a low flooding trend, predominantly smoothwavy reliefs, and most of its area is destined for agriculture and cattle raising. This information will contribute to environmental planning and management, continuity of environmental monitoring programs, as well as expansion of strategic actions towards water resource conservation.

\section{REFERENCES}

Alvares CA, Stape, JL, Sentelhas, PC, Gonçalves, LL de M, Sparovek G (2014) Koopen's climate classification map for Brazil. Meteorologische Zeitschrift 22(6):711-28. DOI:https://doi.org/10.1127/0941-2948/2013/0507

Alves WS, Martins AP, Scopel I (2018) Fragilidade Ambiental: Subsídio ao Planejamento e à Gestão da Bacia do Ribeirão da Laje (GO), Brasil. Geografia, Ensino \& Pesquisa 22: 01-17.

Bambolim A, Donde AR (2017) Análise temporal da Microbacia Mariana no município de Alta Floresta, Mato Grosso. Revista de Agricultura Neotropical 4(3):92-96.

Brasil, Ministério das Minas e Energia (1980) Secretaria Geral, Projeto RADAM Brasil. Folha SC-21 Juruena: geologia, geomorfologia, pedologia, vegetação e uso potencial da terra. Rio de Janeiro.

Brito DS, Grangeiro CMM (2015) Análise ambiental da Microbacia Hidrográfica do rio Salamanca, Barbalha, Ceará. GEOSABERES: Revista de Estudos

Geoeducacionais 6(3):72-83.

Cardoso CA, Dias HCT, Soares CPB, Martins SV (2006) Caracterização morfométrica da bacia hidrográfica do rio Debossan, Nova Friburgo, RJ. Revista Árvore 30(2):241248. DOI: http://dx.doi.org/10.1590/S010067622006000200011.

Claudino WV, Silva EP, Caioni C, Silva ACS, Oliveira AS (2018) Adequação de modelo a susceptibilidade à erosão de solos no âmbito de microbacia na borda sul-amazônica. Revista Ciências Agroambientais 16(2):157-166. DOI: http://dx.doi.org/10.5327/Z1677-606220192770

Claudino WS, Oliveira VAA, Silva EP, Santos SKF, Oliveira AS (2020) Atributos físicos e conservacionistas da bacia hidrográfica do Rio Santa Helena. Nativa 8(1): 91-96. DOI: http://dx.doi.org/10.31413/nativa.v8i1.6953

Cochev JS, Neves SMAS, Silva EP, Silva A, Neves, RJ (2015) Análise fisiográfica e do uso da terra em microbacias com produção olerícola no município de Alta Floresta/MT. Acta Geográfica 9(20):55-71. DOI: http://dx.doi.org/10.5654/acta.v9i20.2002

Congedo, L (2016) Semi-Automatic Classification Plugin Documentation. DOI:

http://dx.doi.org/10.13140/RG.2.2.29474.02242/1

EMBRAPA - Empresa Brasileira de Pesquisa Agropecuária. Serviço Nacional de Levantamento e Conservação de Solos (1979) In: Reunião Técnica de Levantamento de Solos. Rio de Janeiro, Anais...

Ferreira JCV (2001) Mato Grosso e seus Municípios. Cuiabá, Secretaria de Estado de Educação. 365p.
Franco ACV, Santo MAD (2015) Contribuição da morfometria para o estudo das inundações na Sub-Bacia do rio Luís Alves/SC. Mercator 14(3):151-167. DOI: http://dx.doi.org/10.4215/RM2015.1403.0009.

Gonçalves TD, Campos JEG, Batista GT, Diniz HN, Targa MS (2007) Metodologia para elaboração de mapas hidrogeológicos: estudo de caso da bacia hidrográfica do rio da Palma, DF, Brasil. Ambi-Agua 2(2):47-68. DOI: http://dx.doi.org/10.4136/ambi-agua.26

Guidolini J, Ometto J, Arcoverde G, Giarolla A (2020) Environmental Land Use Conflicts in a Macroscale River Basin: A Preliminary Study Based on the Ruggedness Number. Water 12(5):1222. DOI: https://doi.org/10.3390/w12051222

Hellden U, Stern M (1980) Evaluation of Landsat Imagery and Digital Data for Monitoring Desertification Indicators in Tunisia. In: International Symposium on Remote Sensing. San Jose, Proceedings...

IBGE - Instituto Brasileiro De Geografia e Estatística (2019) Cidades. Available:

https://cidades.ibge.gov.br/brasil/mt/altafloresta/panorama. Accessed Maio 14, 2020

Landis JR, Koch GG (1977) The measurement of observer agreement for categorical data. Biométricas 33:159-174.

Llano, XC (2019) AcATaMa - QGIS plugin for Accuracy Assessment of Thematic Maps, version XX.XX. Available: https://plugins.qgis.org/plugins/AcATaMa/. Accessed: Abr 10, 2020

Mato Grosso. Secretaria de Estado de Planejamento e Gestão (2001). Available:

http:/geoportal.seplan.mt.gov.br/metadados/srv/por/catalo g.search\#/home. Accessed: Jul 14, 2020.

Oliveira PTS, Sobrinho TA, Steffen JL, Rodrigues DBB (2010) Caracterização morfométrica de bacias hidrográficas através de dados SRTM. Revista Brasileira de Engenharia Agrícola e Ambiental 14 (8): 819-825.

DOI: http://dx.doi.org/10.1590/S141543662010000800005

Oliveira AS, Pierangeli MAP, Sousa JB de (2019) Características do meio físico da Bacia Hidrográfica do Médio Curso do Rio Teles Pires, no Município de Alta Floresta - MT. Revista Equador 8(3):159-177.

Pessi DD, Loverde-Oliveira SM (2019) Aplicação da análise geoespacial para caracterização da fragilidade de terrenos. Revista de Geografia 36(1):243-260.

Polachini R, Deluski EC, Santos SKF, Claudino WV, Silva EP (2018) Mapeamento da expansão agrícola no município de Alta Floresta, MT no período de 2008 a 2015. Agrarian Academy 5(9):377-389.

Roboredo D, Bergamasco SMPP, Gervazio W (2017) Diagnóstico dos agroecossistemas da Microbacia Hidrográfica Mariana no Território Portal da Amazônia, Mato Grosso, Brasil. Sustentabilidade em Debate 8(1):8094. DOI: https://doi.org/10.18472/SustDeb.v8n1.2017.18840 
Schumm SA (1956) Evolution of drainage systems and slopes in badlands of Perth Amboy. Geological Society of America Bulletin 67(5): 597-646.

Silva CAF da, Bampi AC (2019) Regional Dynamics of the Brazilian Amazon: between Modernization and Land Conflicts. Cuadernos de Geografía: Revista Colombiana de Geografía 28(2):340-356. DOI:

https://doi.org/10.15446/rcdg.v28n2.72872

Silva FL, Heidrich KJ, Silva MHM, Castro SO, Teixeira SO (2019) Desenvolvimento e produção do capim BRS quênia submetido a doses de adubação nitrogenada. Revista Agrária Acadêmica 2(4):110-118. DOI: https://doi.org/10.32406/v2n42019/110-118/agrariacad

Simonetti VC, Silva DCC, Oliveria RAS, Rosa AH (2018) Análise da suscetibilidade do solo a processos erosivos do parque natural municipal corredores de biodiversidade (PNMCBIO) de sorocaba (SP). Raega - O Espaço Geográfico em Análise 44:169-180.

SOJAMAPS (2020). GAAF-Geotecnologia aplicada em agricultura e floresta. Available:

http://pesquisa.unemat.br/gaaf/sojamaps. Accessed: Jun 10,2020

Souza APS, Souza IS, Olavo G, Lobão JSB, São José, RV (2019) Mapeamento e identificação de vetores responsáveis pela supressão do manguezal na Zona Costeira do Baixo Sul da Bahia, Brasil. Revista Brasileira de Geografia Física 12(07):2503-2521.
Strahler AN (1957) Quantitative analysis of watershed geomorphology. Transaction of American Geophysical Union 38:913-920.

Teodoro VLI, Teixeira D, Costa DJL, Fuller BB (2007) O conceito de Bacia Hidrográfica e a importância da caracterização morfométrica para o entendimento da dinâmica ambiental local. Revista Uniara (20):137-156. DOI: https://doi.org/10.25061/25272675/ReBraM/2007.v11i1.236

Tucci CEM, Clarke RT (1997) Impacto das mudanças de cobertura vegetal no escoamento: Revisão. Revista Brasileira de Recursos Hídricos 2(1):135-152. DOI: https://doi.org/10.21168/rbrh.v2n1.p135-152.

Tucci CEM (2004) Hidrologia: ciência e aplicação. Porto Alegre, ABRH. 943 p.

Villela SM, Mattos A (1975) Hidrologia aplicada. São Paulo, McGraw-Hill do Brasil. 245p.

Wisler CO, Brater, EF (1964) Hidrologia. Tradução e publicação de Missão Norte-Americana pela Cooperação Econômica e Técnica no Brasil. Rio de Janeiro, Ao Livro Técnico.

Zaiatz APSR, Zolin CA, Vendrusculo, LG, Lopes TR, Paulino, J (2018) Agricultural land use and cover change in the Cerrado/Amazon ecotone: A case study of the upper Teles Pires River basin. Acta Amazonica 48(2):168-177. DOI: http://dx.doi.org/10.1590/1809-4392201701930 